\title{
The Baltic Sea and Lake Baikal underwater bio-optical fields simulation using ecodynamical model
}

\author{
S.V. Semovski * \\ Limnological Institute SB RAS, PO Box 4199, ul. Ulan-Batorskaya, 3, Irkutsk 664033, Russia
}

Received 31 March 1998; accepted 19 August 1998

\begin{abstract}
The variability of the optical components concentration in water column has been simulated for coastal sea and deep lake basing on the ecosystem dynamic modeling concepts. Phytoplankton, zooplankton and bacterioplankton are included in the model as biological variables. The simulation of underwater optical field takes into account the impact of pure water, chlorophyll pigments absorption, optical features of the 'yellow substance' associated with dissolved organic matter and two fractions of the suspended matter. The model developed have been applied to simulate the spring bloom in the Gulf of Gdansk (Southern Baltic) along the transect and to describe annual ecosystem cycle in water column in Lake Baikal. (C) 1999 Elsevier Science B.V. All rights reserved.
\end{abstract}

Keywords: Water ecosystem; Phytoplankton; Modeling; Hydrooptics

\section{Introduction}

The growing importance of the studies of lake and marine ecosystems continually calls for development of more and more precise models describing both physical and biological components of environment. The main attention should be paid to the physical factors (underwater optical field

* Tel.: + 7-3952-460768; fax: + 7-3952-466933; e-mail: semovsky@lin.irk.ru. and local hydrodynamics), on which the living species life cycle mostly depends. Optical characteristics are of a special importance because photosynthesis directly depends on them thus determining the level of biomass production. In the studies of Jerlov, Morel, Platt, Sathyendranath, Kopelevich, Pelevin, Wozniak (see, e.g. references in Wozniak et al., 1992, 1995) the basis was constructed for the underwater light field description using known vertical structure of phytoplankton and other optical factors. The articles of Wozniak (Wozniak et al., 1992, 1995) should 
Table 1

The state variables of the model

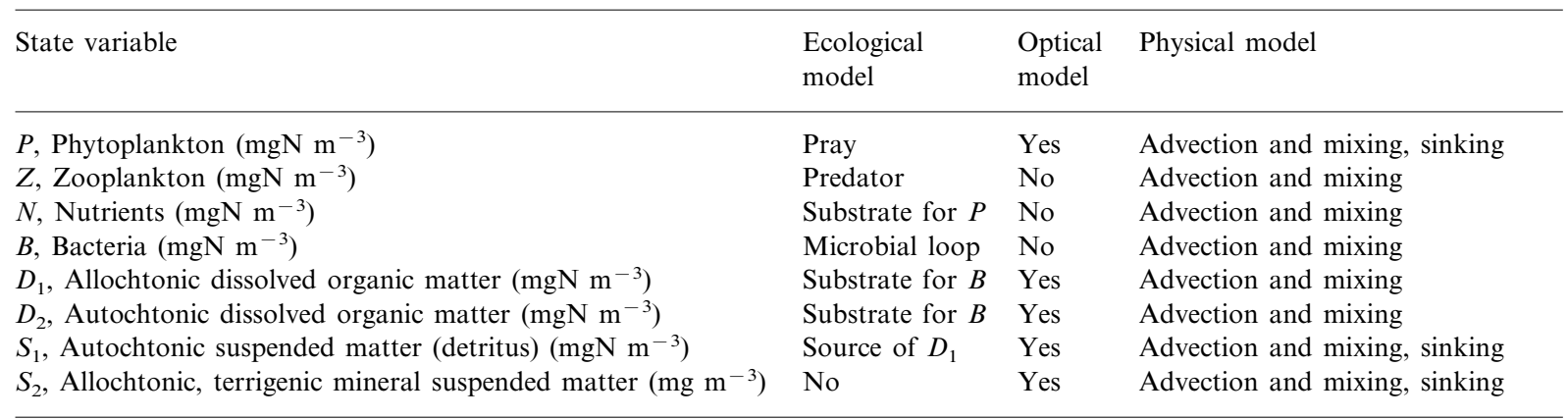

and surface chlorophyll concentration. This made it possible to merge bio-optical algorithm and ecodynamics model to simulate phytoplankton dynamics and spectral irradiance field variations in the water column. The attempt to develop such model has been made in the author's previous papers (Semovski and Wozniak, 1994; Semovski et al., 1996). The only optically active component taken into account by the model was concentration of chlorophyll pigments of living phytoplankton cells. In these studies the method was proposed as well for remote sensing data and in situ observations numerical assimilation.

However, when describing the processes in the coastal waters, which are the most productive, dynamics of other optically active components independent of phytoplankton should be included in the model. The same holds for lakes.

Here we present the model generalization, which includes not only chlorophyll, but also two fractions of dissolved organic matter (DOM) associated with optically detected 'yellow substance' and two fractions of suspended matter. Examples of the model application are presented for the Southern Baltic coastal waters (Gulf of Gdansk) and for Lake Baikal. These geographical objects differ considerably by biooptical conditions, however, the comparison with experimental observations shows satisfactory qualitative agreement.

\section{Techniques}

The ecodynamical bio-optical model consists of three main parts:

- The vertically resolved biological block equations, which are based on general principles of population dynamics. The algorithm includes the primary production term directly depending of spectral underwater irradiance.

- The local hydrodynamic physical model can be used in different possible forms, full three-dimensional advection and mixing field simulation, two-dimensional (for example, on the transect), or one-dimensional (water column model).

- The model of underwater optical field uses vertical concentration of biological and mineral optically active components for the vertical spectral irradiance profile derivation.

The state variables of the model are outlined in the Table 1. Processes in the physical block controlled every state variable are noted, variable role in the biological block and information if this variable is included in the optical block. All variables are in nitrogen units. We use nitrogen/ chlorophyll relations after (Semovski and Wozniak, 1994). The main parameters of the model are presented in Table 2. Numerical values of the parameters in Table 2 are those used as in our previous studies (Semovski and Wozniak, 1994; Semovski et al., 1996). In Table 3 the external functions of the model are presented, namely, source functions and sinking terms. 
Table 2

Parameters of the model and its values

\begin{tabular}{|c|c|c|}
\hline Parameter & Description & Value \\
\hline \multicolumn{3}{|c|}{ Ecosystem model } \\
\hline$k_{S}$ & Nutrient half-saturation $\left(\mathrm{mgN} \mathrm{m}^{-3}\right)$ & 0.2 \\
\hline$R_{\mathrm{m}}$ & Max herbivore ingestion rate $\left(\mathrm{d}^{-1}\right)$ & 0.45 \\
\hline$L$ & $\begin{array}{l}\text { Ivlev herbivore grazing constant } \\
\left(\mathrm{m}^{3} \mathrm{mgN}\right)\end{array}$ & 0.5 \\
\hline$\beta$ & $\begin{array}{l}\text { Unassimilated fraction of herbivore } \\
\text { grazing ration (dimensionless) }\end{array}$ & 0.3 \\
\hline$\gamma_{P}$ & Phytoplankton mortality rate $\left(\mathrm{d}^{-1}\right)$ & 0.12 \\
\hline$\gamma_{Z}$ & Zooplankton mortality rate $\left(\mathrm{d}^{-1}\right)$ & 0.05 \\
\hline$\gamma \mathbf{B}$ & $\begin{array}{l}\text { Bacterioplankton mortality rate } \\
\left(\mathrm{d}^{-1}\right)\end{array}$ & 0.2 \\
\hline$Y_{B}$ & $\begin{array}{l}\text { Unassimilated fraction of bacteria } \\
\text { ration, dimensionless }\end{array}$ & 0.3 \\
\hline$b_{\mathrm{MAX}}$ & $\begin{array}{l}\text { Maximum rate of DOM uptake } \\
\left(d^{-1}\right)\end{array}$ & 0.32 \\
\hline$k_{D, 1}$ & $\begin{array}{l}D_{1} \text { half-saturation constant } \\
\left(\mathrm{mgN} \mathrm{m}^{-3}\right)\end{array}$ & 5.0 \\
\hline$k_{D, 2}$ & $\begin{array}{l}D_{2} \text { half-saturation constant } \\
\left(\mathrm{mgN} \mathrm{m}^{-3}\right)\end{array}$ & 0.5 \\
\hline$\sigma$ & $\begin{array}{l}\text { Detritus autolysis rate, dimension- } \\
\text { less }\end{array}$ & 0.05 \\
\hline \multicolumn{3}{|c|}{ Physical model } \\
\hline$w_{P}$ & Phytoplankton sinking rate $\left(\mathrm{m} \mathrm{d}^{-1}\right)$ & 0.4 \\
\hline$w_{S_{1}}$ & Detritus sinking rate $\left(\mathrm{m} \mathrm{d}^{-1}\right)$ & 1.0 \\
\hline$w_{S_{2}}$ & $\begin{array}{l}\text { Mineral suspended matter sinking } \\
\text { rate }\left(\mathrm{m} \mathrm{d}^{-1}\right)\end{array}$ & 1.5 \\
\hline
\end{tabular}

\section{The biological model}

\subsection{Phytoplankton}

The model treats all autotrophic planktonic cells as a single group without discriminating at this point between photosynthesizing taxa and designates this group as 'phytoplankton'. The ne-

Table 3

Source and sinking functions in the model

\begin{tabular}{ll}
\hline$N_{S}(z)$ & Nutrient inflow \\
$D_{S}(z)$ & DOM inflow \\
$S_{S}(z)$ & Mineral suspended matter inflow \\
$W_{P} \frac{\partial P}{\partial z}$ & Phytoplankton gravitational sinking \\
$W_{S_{1}} \frac{\partial S_{1}}{\partial z}$ & Detritus gravitational sinking \\
$W_{S_{2}} \frac{\partial S_{2}}{\partial z}$ & Mineral suspended matter gravitational sinking \\
\hline
\end{tabular}

cessity of this simplification dues to difficulties of further taxonomic discrimination basing on their biooptical characteristics such as content of different forms of pigments and different photosynthesis rates.

The model uses the following equations for the phytoplankton dynamics, similar to those used in (Semovski and Wozniak, 1994; Semovski et al., 1996).

$$
\begin{aligned}
\frac{\partial P}{\partial t}= & F(x, y, z, P)+w_{P} \frac{\partial P}{\partial z}+\omega(N) \operatorname{Pr}(P, z) \\
& -\operatorname{Cons}(P, Z)-\gamma_{P} P .
\end{aligned}
$$

Here $(x, y, z)$ are space coordinates, vertical coordinate $z$ directed downward, $F()$ is an advectiondiffusion term, describing by the physical model, $w_{P}$ is the phytoplankton sinking rate, the nutrient limitation term is $\omega(N)=N /\left(k_{S}+N\right)$ primary production term $\operatorname{Pr}(P)$ will be described in the next chapter, consumption by zooplankton term in Ivlev form is $\operatorname{Cons}(P, Z)=R_{\mathrm{m}} \operatorname{LPZ}[1-\exp (-$ LP)], for the phytoplankton mortality we use first-order kinetics.

\subsection{Photosynthetic primary production}

The primary production term $\operatorname{Pr}(P, z)$ in Eq. (1) is the basic process in a marine ecosystem carbon and energy cycles. It is known that spectral representation of the underwater irradiance field for the primary production computation leads to a more adequate description of water ecosystem dynamics (see, e.g. Gregg and Walsh, 1992). Between models of photosynthesis rate dependence of a spectral downward irradiance (Morel, Platt et al.) we choose Wozniak model (Wozniak et al., 1992, 1995). This algorithm uses a quantum yield of photosynthesis attempt. Photosynthetic primary production is calculated by the equation $\operatorname{Pr}(P, z)=\Phi(P, z) \times \eta_{\mathrm{PUR}}(P, z)$, where $\Phi(P, z)$ is the quantum yield of photosynthesis, $\left(\mathrm{mgN}_{\mathrm{quanta}}^{-1}\right)$, it depends on a phytoplankton concentration, $\eta_{\mathrm{PUR}}(P, z)$ represents energy absorbed by phytoplankton, (quanta $\mathrm{m}^{-3}$ ) and it depends on the available irradiance field on the depth $z$ and on a phytoplankton pigments absorption. This algorithm was used successfully for the World Ocean and the Baltic studies. 
Main equations of the method can be found as well in (Semovski and Wozniak, 1994; Semovski et al., 1996).

\subsection{Zooplankton, higher trophic levels}

Like in the case of phytoplankton (see Section 3.1), here we use a single variable (zooplankton) in the model for broad class of species, which are grazers for autotrophic plankton. This wide group may include copepods as well as flagellates, which are grazers respectively for picoplankton and nanoplankton. A bigger phytoplankton fraction may be predated by fish. Since the variable representing zooplankton state is not included to the optical model, it can be seemingly considered as some balance and ecological limitation term in the biological block of the model.

For zooplankton dynamics equation has another form similar to those used in our previous studies.

$$
\frac{\partial Z}{\partial t}=F(x, y, z, Z)+(1-\beta) \operatorname{Cons}(P, Z)-\gamma_{Z} Z,
$$

where first-order kinetics is used for mortality and $(1-\beta) \operatorname{Cons}(P, Z)$ is assimilated fraction of herbivore ration (see Section 3 and Table 2).

\subsection{Microbial loop}

A bacterioplankton block included into the model is necessary for simulation of dissolved organic matter dynamics. Part of the DOM constituents (mostly humic substances) may be associated with optically active yellow substance (or Gelbshtoff) (Carder et al., 1989; Coble and Brophy, 1994). For the case 1 waters, where all optically properties are well correlated with phytoplankton chlorophyll pigments, models without bacteria and DOM blocks are capable to describe optical field rather well (Semovski et al., 1996). As the first approximation for the case 2 water objects like Baltic or Lake Baikal, the average additional term describing DOM and not correlated to a phytoplankton concentration (see Kaczmarek and Wozniak, 1995; Semovski et al.,
1995; Wozniak et al., 1995) can be included into the optical model. When taken into account by the optical model, this term considerably changes the resulting vertical phytoplankton dynamics.

It seems more appropriate if we simulate DOM dynamics in the ecosystem, that is, the DOM arrival with river runoff as well as with partial dissolution of detritus and DOM assimilation by heterotrophic bacteria. In the last years a progress was made in microbial loop studies and modeling for the marine environment (Jumars et al., 1989; Billen, 1990; Baretta-Bekker et al., 1995). Here we use after (Lancelot and Billen, 1990) the following equations for bacteria state variable dynamics

$\frac{\partial B}{\partial t}=F(x, y, z, B)+Y_{B} \operatorname{Upt}\left(B, D_{1}, D_{2}\right)-\gamma_{B} B$,

where DOM uptake by bacteria is strongly dependent on the temperature $(T)$

$\operatorname{Upt}\left(B, D_{1} D_{2}\right)$

$$
=b_{\max } \mu_{B}(T) B\left(\frac{D_{1}}{k_{D, 1}+D_{1}}+\frac{D_{2}}{k_{D, 2}+D_{2}}\right)
$$

$\mu_{B}(T)=B_{\text {MAX }}\left\{0.1+0.9 \exp \left[-\frac{(T-18)^{2}}{7}\right]\right\}$

Note that function of temperature dependence was derived using the North Sea and Antarctic observational data.

\subsection{Dissolved organic matter}

Interest in DOM dynamics investigations has increased in the last years along with the development of optical methods for water ecosystems monitoring (see Section 3.4). However, the knowledge of the DOM role in marine ecosystem, its annual variability and optical properties is far from complete (see Pempkowiak, 1988; Lignell, 1990; 40 references in Coble and Brophy, 1994 and other studies).

Presented model of the two dissolved organic matter fractions $\left(D_{1}\right.$ and $\left.D_{2}\right)$ dynamics is based on (Lancelot and Billen, 1990) ideas. 


$$
\begin{aligned}
\frac{\partial D_{1}}{\partial t}= & F\left(x, y, z, D_{1}\right)+\sigma S_{1}-b_{\max } \mu_{B}(T) B \frac{D_{1}}{k_{D, 1}+D_{1}} \\
\frac{\partial D_{2}}{\partial t}= & F\left(x, y, z, D_{2}\right)-b_{\max } \mu_{B}(T) B \frac{D_{2}}{k_{D, 2}+D_{2}} \\
& +D_{S}(z)
\end{aligned}
$$

where $\sigma S_{1}$ is the term of partial detritus autolysis, $D_{S}(z)$ is an external dissolved organic matter inflow due to river influx and sediments resuspension (see Table 3 ). These equations can be viewed as a first attempt to describe DOM dynamics more adequately in future. It is possible, that the proper model should be developed specifically for different water objects.

\subsection{Nutrients}

The state variable corresponding to nutrients is usual for marine ecosystem models. Its role is to describe a current limited biologically neutral environmental factor (substrate), which can be different for the different geographical conditions and even for different moments of annual cycle. Often this parameter can be associated with nitrates, phosphorus, ammonia or silicon. A nutrient limitation in upper layer that exists during the spring bloom is one of the reasons of subsurface phytoplankton maximum formation. The specific vertical nitrates structure with low concentration in upper layer and strong nutricline can be observed in summer even for such eutrophic ecosystem as Baltic. For the specific conditions, however, situation may be different. Complicated analysis of limiting nutrient form variability during the annual cycle is beyond the scope of this study (see, e.g. Semovski and Sherstyankin, 1997).

The corresponding nutrient dynamics equation in the model has the following form, which is similar to those used in our previous studies:

$$
\begin{aligned}
\frac{\partial N}{\partial t}= & F(x, y, z, N)+\gamma_{B} B \\
& +\left(1-Y_{B}\right) \operatorname{Upt}\left(B, D_{1}, D_{2}\right)+N_{S}(z) \\
& -\omega(N) \operatorname{Pr}(P),
\end{aligned}
$$

where the first source term is bacterioplankton mortality from Eq. (3), nutrients uptake Upt is defines by Eq. (3.1), $N_{S}(z)$ is an external nutrients inflow (see Table 3) and the last term is nutrient consumption by phytoplankton taken from Eq. (1).

\subsection{Biologically produced and mineral suspended matter}

After Sundermann (1993) we can use in the model two suspended matter fractions, namely, the detritus $\left(S_{1}\right)$ and mineral biologically neutral suspensions $\left(S_{2}\right)$. Equations for fractions dynamics have a following form

$$
\begin{aligned}
\frac{\partial S_{1}}{\partial t}= & F\left(x, y, z, S_{1}\right)+w_{S_{1}} \frac{\partial S_{1}}{\partial z}-\sigma S_{1}+\gamma_{P} P+\gamma_{Z} Z \\
& +\beta \operatorname{Cons}(P, Z) \\
\frac{\partial S_{2}}{\partial t}= & F\left(x, y, z, S_{2}\right)+w_{S_{2}} \frac{\partial S_{2}}{\partial z}+S_{S}(z)
\end{aligned}
$$

where $w_{S_{1}}, w_{S_{2}}$ are corresponding gravitational sinking velocities. The detritus pool supply factors are moralities of phytoplankton and zooplankton and unassimilated fraction of herbivore grazing ration. The external mineral suspended matter inflow $S_{S}(z)$ (see Table 3) can be controlled by river inflow and by resuspension of bottom sediments in case of shallow coastal areas.

\section{The physical model}

The physical block of the model can be chosen from a reasonably large class as the formulation, which the problem requires. It is evident that the processes of vertical mixing and vertical movement are of decisive importance for the behavior of variables of biological nature. If a three-dimensional hydrodynamic circulation field model is available for the object under study and this model produces adequate vertical and horizontal mixing fields, then its incorporation to describe advection and mixing data would be the best decision. The physical term in the base equation for state variable $Q$ will have the following form, $F(x, y, z, Q)=K_{x y z} \times \nabla^{2} Q+\mathbf{U g r a d} Q$

where $K_{x y z}$ is a tensor of turbulent diffusion coefficient and $\mathbf{U}$ is a vector advection field. How- 
ever, for the complicated coastal areas and lakes such detailed models are rare. The two-layer model with different vertical mixing intensities in upper and bottom layers may be used as a simplest decision (Semovski and Wozniak, 1994; Semovski et al., 1996). The depth of upper mixed layer can be taken as its climatic value, calculated using vertical sounding observations or simulation by the upper layer model using wind data. In the article (Semovski et al., 1996) the hybrid model was used, namely, a two-dimensional barotropical model of wind-driven horizontal circulation and two-layer model for vertical mixing.

For the studies of complex mesoscale hydrodynamic events, the specific complex hydrodynamic model should be used. Such events can be threedimensional or two-dimensional along the transect (see examples of upwelling feature and river front transformation simulation on the section in Semovski et al., 1996). Simple examples will be presented in the next chapter for the different water objects

\section{The optical model}

Most of existing models of underwater optical field were developed only for so called case 1 waters according to Morel terminology. Another type of waters, so called case 2 waters, which comprises approximately $2 \%$ of the World Ocean and all of the lake waters, is the most productive one. The eutrophicated Baltic waters can not be described by models suitable for ocean waters. The first bio-optical and primary production model for Baltic waters was developed in the Polish Institute of Oceanology (Kaczmarek and Wozniak, 1995; Wozniak et al., 1995). This model is based on optical observations, chlorophyll $a+$ pheophytin a $\left(\mathrm{C}_{\mathrm{a}}\right)$ observations and data base containing information on quantum yield of photosynthesis. We used this bio-optical model in our previous studies (Semovski and Wozniak, 1994; Semovski et al., 1995). In the presented study a different approach is used for optical field simulation, which is a simple generalization of the Prieur and Sathyendranath (1981) four-component model, see also earlier the Kopelevich and $\mathrm{Bu}$ - renkov (1977) three-component model. The representation of the spectral diffusive attenuation $K_{\mathrm{d}}(\lambda),\left(\mathrm{m}^{-1}\right)$ is used as the sum of components, corresponding to the optical active constituents of water.

$$
\begin{aligned}
K_{\mathrm{d}}(\lambda)= & K_{W}(\lambda)+K_{\mathrm{pl}}(\lambda)+K_{y_{1}}(\lambda)+K_{y_{2}}(\lambda) \\
& +K_{s_{1}}(\lambda)+K_{s_{2}}(\lambda)
\end{aligned}
$$

where $\lambda$ is a wavelength $(\mathrm{nm}), K_{W}(\lambda)$ is a diffusive attenuation of pure water (see values in Wozniak et al., 1992). Diffusive attenuation by cells of autotrophic plankton $K_{\mathrm{pl}}(\lambda)$ can be calculated with respective formulas from (Wozniak et al., 1992).

The terms describing the two kinds of yellow substance $K_{y_{1}}(\lambda), K_{y_{2}}(\lambda)$ correspond to two kinds of DOM in the biological part of the model (see Section 3.5). These terms have a following form, based on general knowledge (Carder et al., 1989; Coble and Brophy, 1994):

$K_{y_{1,2}}(\lambda)=a_{1,2} D_{1,2} \exp \left[-\beta_{1,2}(\lambda-400)\right]$

The specific form of expressions can be controlled by local conditions. Particularly it is true for terrigenic (allochtonic) DOM and corresponding yellow substance fraction.

For the Baltic coastal ecosystem simulations we use values taken from observations (Kowalczuk and Kaczmarek, 1996): for the allochtonic fraction the value observed near the Vistula mouth $\beta_{2}=0.012\left(\mathrm{~nm}^{-1}\right)$ and for the autochtonic fraction the value observed in the open sea waters $\beta_{1}=0.019\left(\mathrm{~nm}^{-1}\right)$. Important factor for the consideration is the dependence between DOM concentration expressed in nitrogen units and correspondent yellow substance attenuation describing by coefficients $a_{1,2}$. We use empirical relations between attenuation on the fixed wavelength and carbon content in dissolved organic matter contained in the same water sample, which had been calculated from experimental data (Dera et al., 1978) as $K_{y_{1}}=0.097 \ln C_{y}+0.17$. The nitrogen to carbon ratio in dissolved organic matter of Southern Baltic was taken from (Pempkowiak, $1988)$ and was set to $0.07 \quad\left(\mathrm{mgN} \mathrm{mgC}^{-1}\right)$. It should be noted, however, that Pempkowiak argued that there was no dependence be- 
tween optical properties and DOM carbon content in Southern Baltic samples. Seemingly, data obtained by Dera et al. (1978) and SamulaKoszalska and Wozniak (1979) suggests the opposite. For mineral suspended matter, which has, in common opinion, nonspectral character of attenuation (Dera et al., 1978) we use the following form $K_{\mathrm{sm}_{2}}(\lambda)=a_{\mathrm{sm}_{2}} S_{2}$, where $a_{\mathrm{sm}_{2}}$ is chosen empirically. For biogenic suspended matter we calculated the following functional approximation using observations for the Baltic by Siegel et al. (1994):

$$
K_{\mathrm{sm}_{1}}(\lambda)=a_{S_{1}} \exp [-0.00683(\lambda-43.5)], a_{S_{1}}=0.1
$$

The description of the Baikal phytoplankton under-ice bloom requires incorporation of the ice spectral light transmission in the photosynthetically active radiation (400-700 $\mathrm{nm}$ ) band. We used experimental data by Sherstyankin (1975) for the Baikal clean ice, which is exceptionally transparent (light transmission is up to $80 \%$ ) and for the ice covered by snow (transmission is about $20 \%$ ). The choice between clean and snow-covered ice had been performed randomly in course of simulations.

\section{Results}

\subsection{Spring bloom in the Vistula river plume area, Southern Baltic}

The Baltic Sea is one of the world's best studied water objects. Regular research cruises of Institute of Oceanology PAS, Sopot, Poland allow an understanding of main factors forming optical fields in the Southern Baltic. In Wozniak et al. (1995) studies the first model had been developed for specific Baltic bio-optical fields and simulation of primary production. In the Baltic model we use main relations deduced in previous studies (see Semovski and Wozniak, 1994; Semovski et al., 1996). Well-studied coastal area in the Southern Baltic was chosen for the simulation, namely, the Gulf of Gdansk and the Vistula mouth region. The strong salinity stratification defined by the river plume influence and advective nutrient inflow tends to increase phytoplankton concentra- tion around the year. High concentration may occur as well due to specific hydrodynamical features such as fresh water front transformation (see Semovski et al., 1995). The phytoplankton annual cycle typical for this latitude can be observed in the open Baltic waters. Two peaks during spring and summer are peculiar to this cycle (see e.g. Witek, 1995). Processes in the transition zone can be very complicated due to advection field variability and the detritus inflow from the river plume area (see an example in Semovski et al., 1996).

We present simulation studies of the simplest case: a spring bloom simulation along the transect orthogonal to coast for the slope river front position and constant advection field. Table 2 lists parameter values.

Simulation results for the Vistula mouth area inside the Gulf of Gdansk are presented in Fig. 1. Beginning of spring bloom is clearly expressed in the phytoplankton distribution, followed by concentration decline in the open sea and it still remains high in the river mouth area. It is wellknown, that zooplankton concentration increases after the phytoplankton bloom in the beginning of summer. During the same period nutrients content in the surface layer growth due to DOM regeneration by bacteria and river inflow. This may course the second bloom in the end of summer. Variability of bacteria is correlated with zooplankton and is in agreement with observations (Witek, 1995). Biogenic DOM and suspended matter distribution is correlated with the phytoplankton and the most dense in river mouth area. Mineral suspended matter and allochtonic DOM distribution have small variations during the year due to the stationary advection field assumed.

Results of the underwater attenuation field simulation are presented in Fig. 2. For the comparisons with observations we use observed spectra of diffusive attenuation coefficients for downwelled irradiance that were measured by author and R. Hapter on 7 May 1994, using an apparatus constructed in the Institute of Oceanology of the Polish Academy of Sciences (Wozniak and Montwill, 1973). The spectrophotometer has eight interference filters for the following wavelengths: 

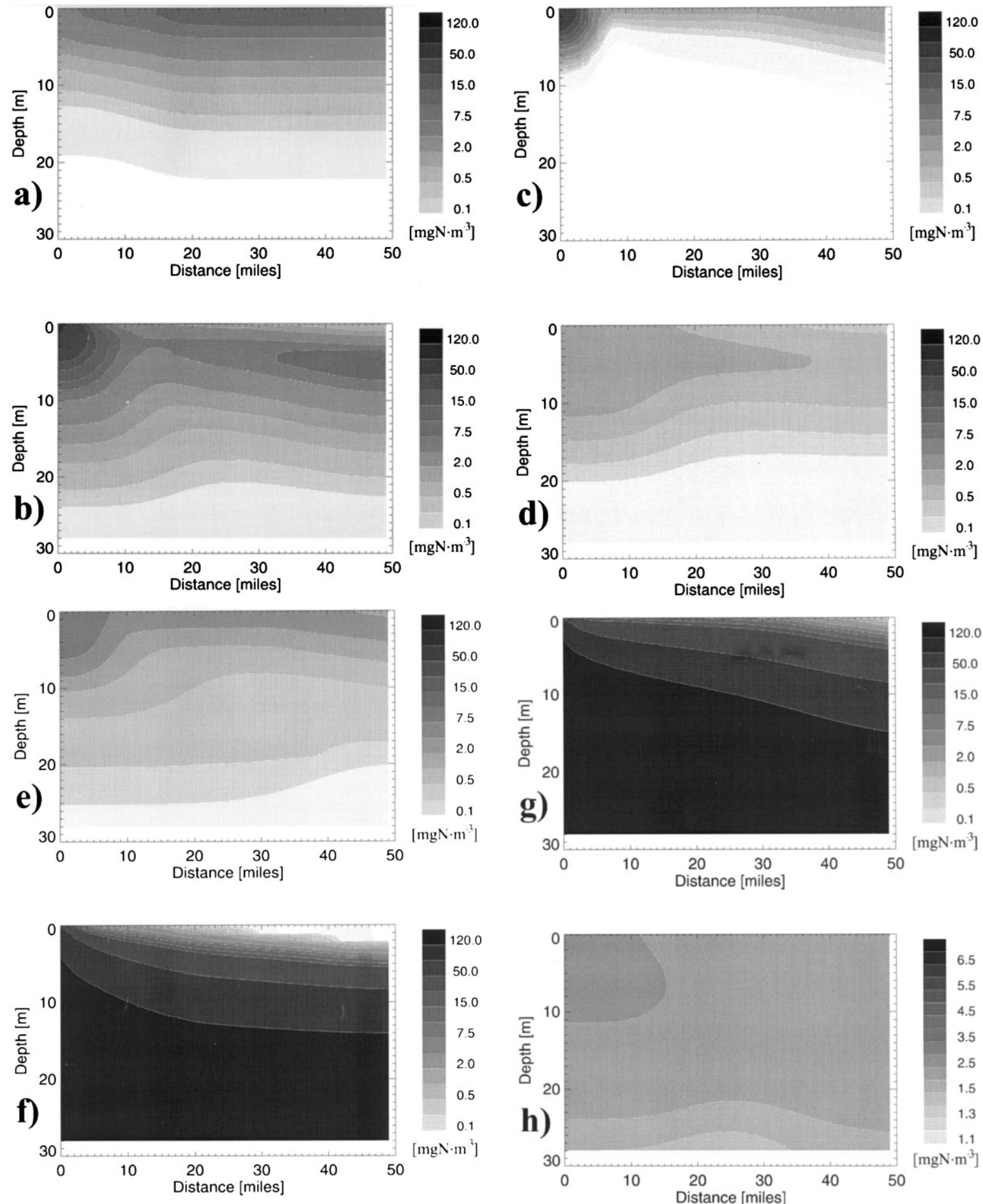

Fig. 1. Gulf of Gdansk phytoplankton spring bloom, concentration $\left(\mathrm{mgN} \mathrm{m}^{-3}\right)$ on the section. Phytoplankton: (a) 3 March; (b) 30 April; (c) 30 June, zooplankton; (d) 30 April; (e) 30 June, nutrients; (f) 30 April, (g) 30 June, bacteria; (h) 30 April; (i) 30 June, $D_{1}$; (j) 30 June, $D_{2}$; (k) 30 June, $S_{1}$; (l) 30 June, $S_{2}$; and (m) 30 June. 

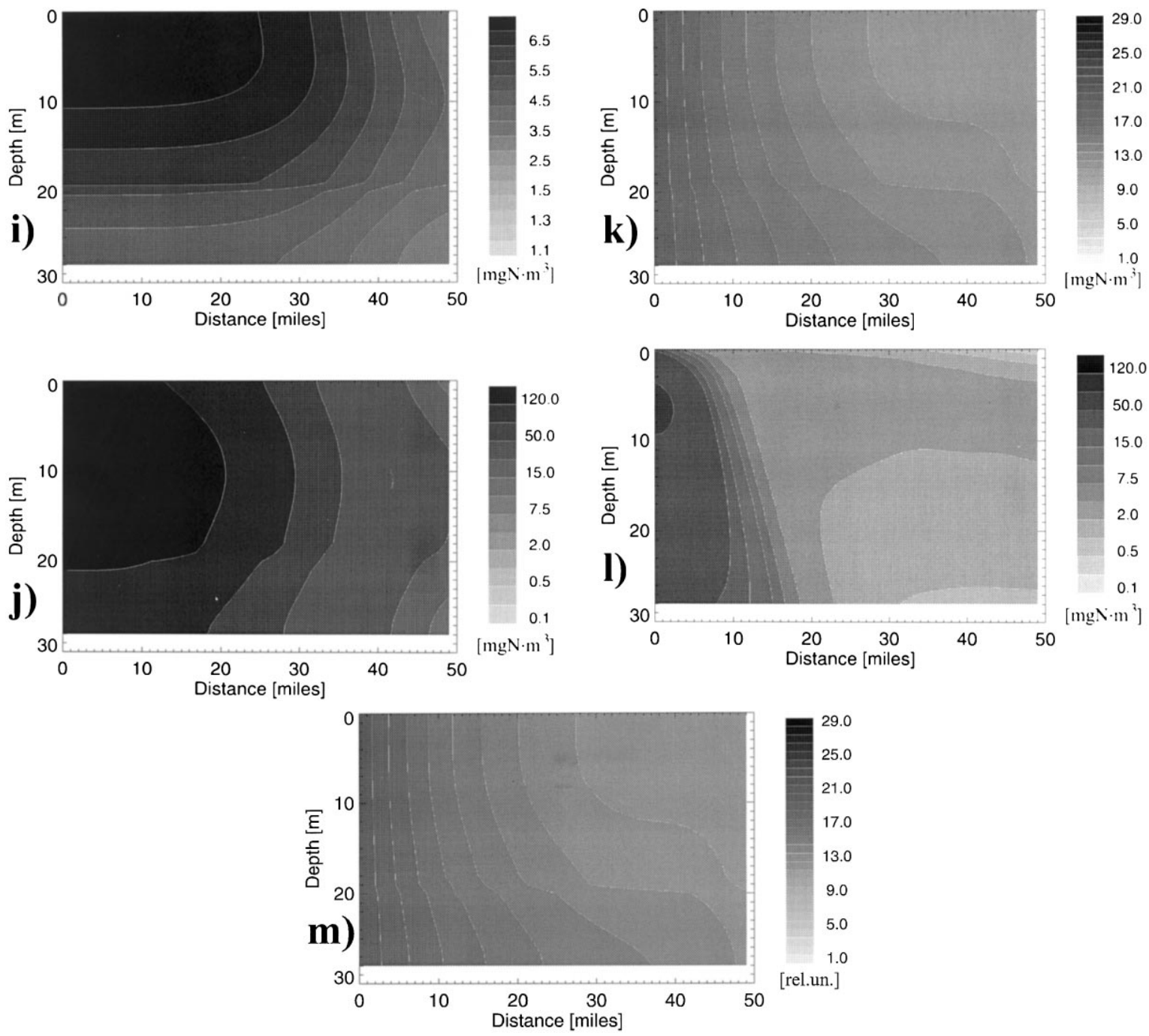

Fig. 1. (Continued)

400, 425, 465, 525, 535, 580, 620 and $680 \mathrm{~nm}$. Note that, when concentration of pigment was high, spectra on the Fig. 2e were calculated only for the top $10 \mathrm{~m}$ due to insufficient instrument sensitivity. Comparisons of simulation results with data on variability of biological components Witek, 1995) and with observed optical fields show the satisfactory qualitative agreement.

\subsection{Lake Baikal phytoplankton annual cycle}

Lake Baikal, situated in the south-eastern
Siberian Russia, is the deepest and most voluminous lake on the earth (Kozhov, 1963). The extraordinary depth (down to $1642 \mathrm{~m}$ ) of the lake is an important factor influencing seasonal temperature dynamic. Low stability of water column defines a deep mixing phenomena during autumn-winter cooling and spring heating periods. During the summer (July-September) and the winter (February-April) the stable stratification occurs, with a colder under-ice upper layer in winter (see Korotenko and Sukhov, 1991; Shimaraev et al., 1994). 

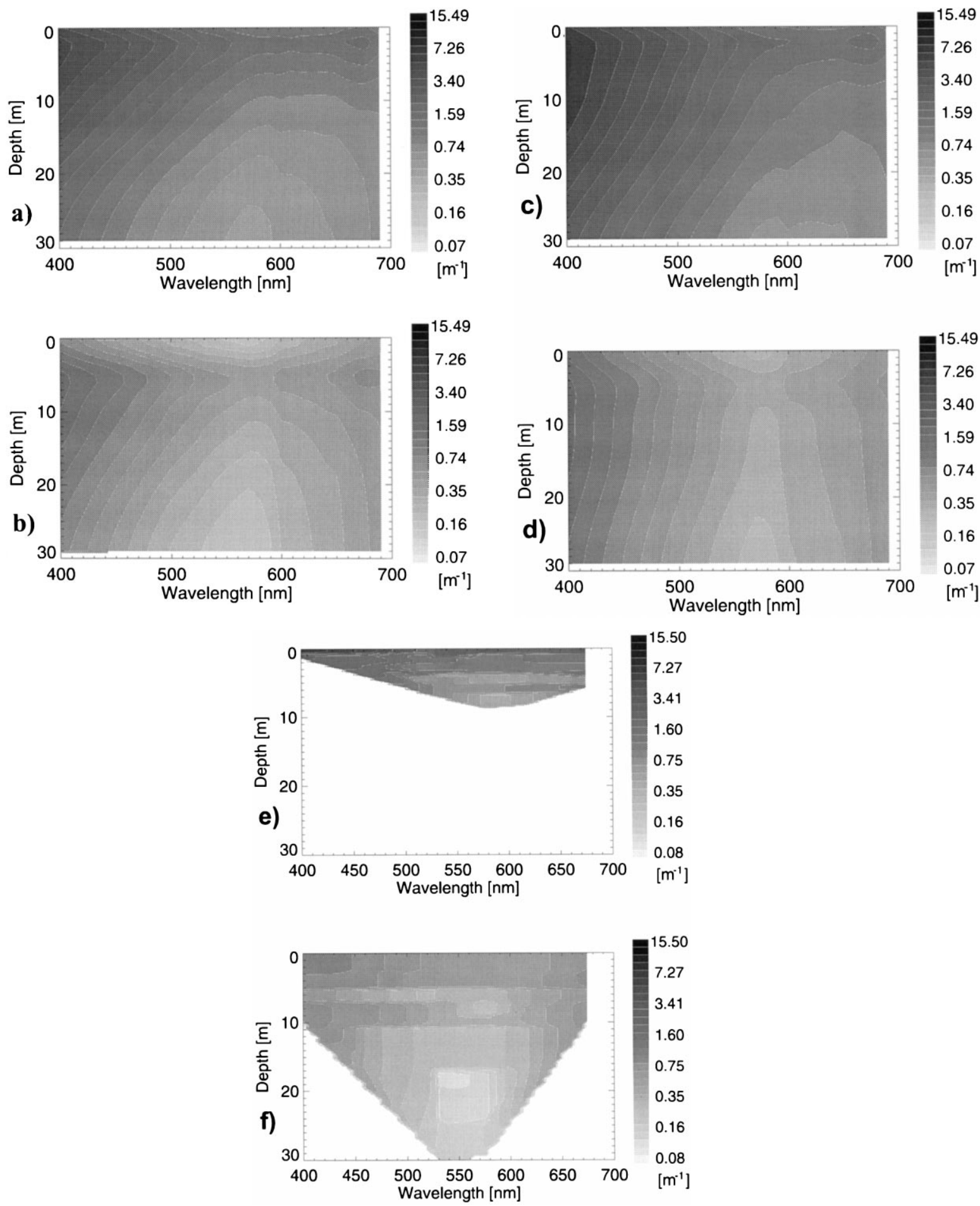

Fig. 2. Spectral diffusive attenuation coefficient $K_{\mathrm{d}}\left(\mathrm{m}^{-1}\right)$ vertical structure for the points on the Gulf of Gdansk section. Model, 15 March: (a) point 2 (river mouth); (b) point 38 (open Baltic), 30 April; (c) point 2; (d) point 38. Observations, 7 May 1994; (e)

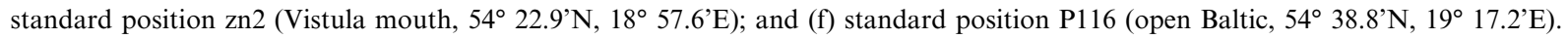


The winter-spring under-ice phytoplankton bloom (mostly diatom) is typical for Baikal. $\mathrm{C}_{\mathrm{a}}$ concentrations of algae reach up to $10 \mathrm{mg} \mathrm{m}^{-3}$ (Kozhova et al., 1985). The summer phytoplankton concentrations are usually lower and picoplankton fraction may prevail. Nitrogen and phosphorus concentrations are low during summer in the upper layer and can limit algal growth (Votincev et al., 1975). Silicon may be a limiting nutrient as well if diatoms exhausted it during their bloom to build their frustules (Votincev et al., 1975, see as well model of Semovski and Sherstyankin, 1997). The review of Lake Baikal ecodynamics models of box structure can be found in (Silow et al., 1995).

The low bacteria activity due to the low temperature is supposedly the reason for relatively high dissolved organic matter impact in Baikal waters optical properties even on the maximal depth (Karabashev et al., 1989; Shimaraev et al., 1994; Dobrynin et al., 1997). In the last study an average yellow substance attenuation term in the bottom layer was estimated as follows:

$$
\begin{aligned}
& K_{y s}(\lambda)=K_{y s, 390} \exp [-\mu(\lambda-390)], \\
& \quad K_{y s, 390} \approx 0.141\left(\mathrm{~m}^{-1}\right), \quad \mu=0.0166\left(\mathrm{~nm}^{-1}\right)
\end{aligned}
$$

In the same time Baikal waters are extremely transparent and Secchi disk visibility depth in June reaches $40 \mathrm{~m}$.

For the simulation of annual cycle the general assumptions of the model have been applied. More detailed studies should be performed to estimate such the specific Baikalian characteristics as optical properties of allochtonic dissolved organic matter or specific absorption of phytoplankton. In our opinion, the Wozniak optical and primary production model still suitable to be applied for specific Baikal features qualitative description. Calculations were made for the following scenarios:

1. Clear ice during all the winter,

2. Snow-covered ice during the whole winter and

3. Snow-covered ice occurred with $90 \%$ probability by random choice.

Fig. 3 demonstrates the results of simulation of the phytoplankton annual structure variation under scenarios $(a-c)$. All major features of annual structure such as, under-ice bloom, algal abundance drop during spring due to homothermy and intensive mixing, the surface-borne summer bloom may be seen on the charts presented. The surface snow shading in winter courses much more intense summer bloom due to higher amount of unassimilated nutrients in spring.

In general, simulations corroborate the observations (Kozhova et al., 1985). Unfortunately
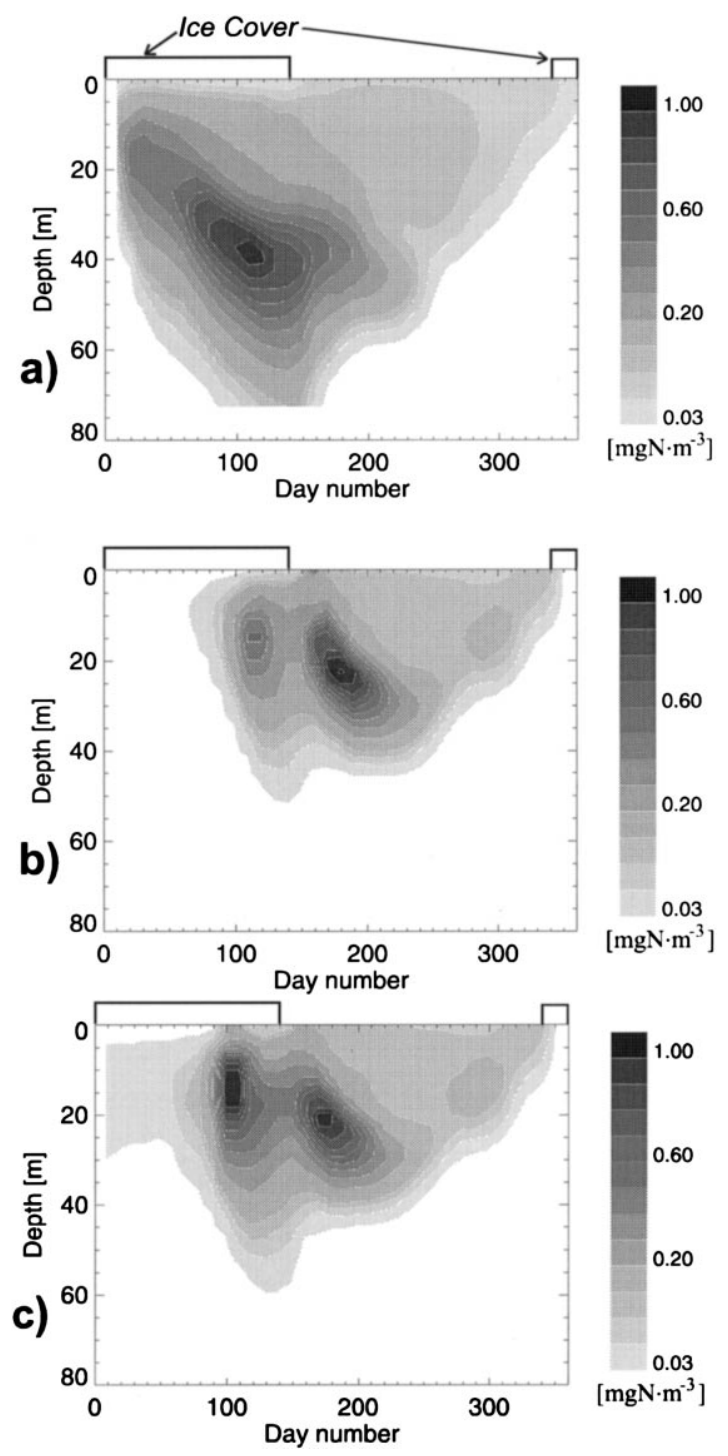

Fig. 3. Lake Baikal phytoplankton annual cycle $\left(\mathrm{mgN} \mathrm{m}^{-3}\right)$ : (a) Clean ice; (b) Snow-covered ice; and (c) Random snow coverage. 

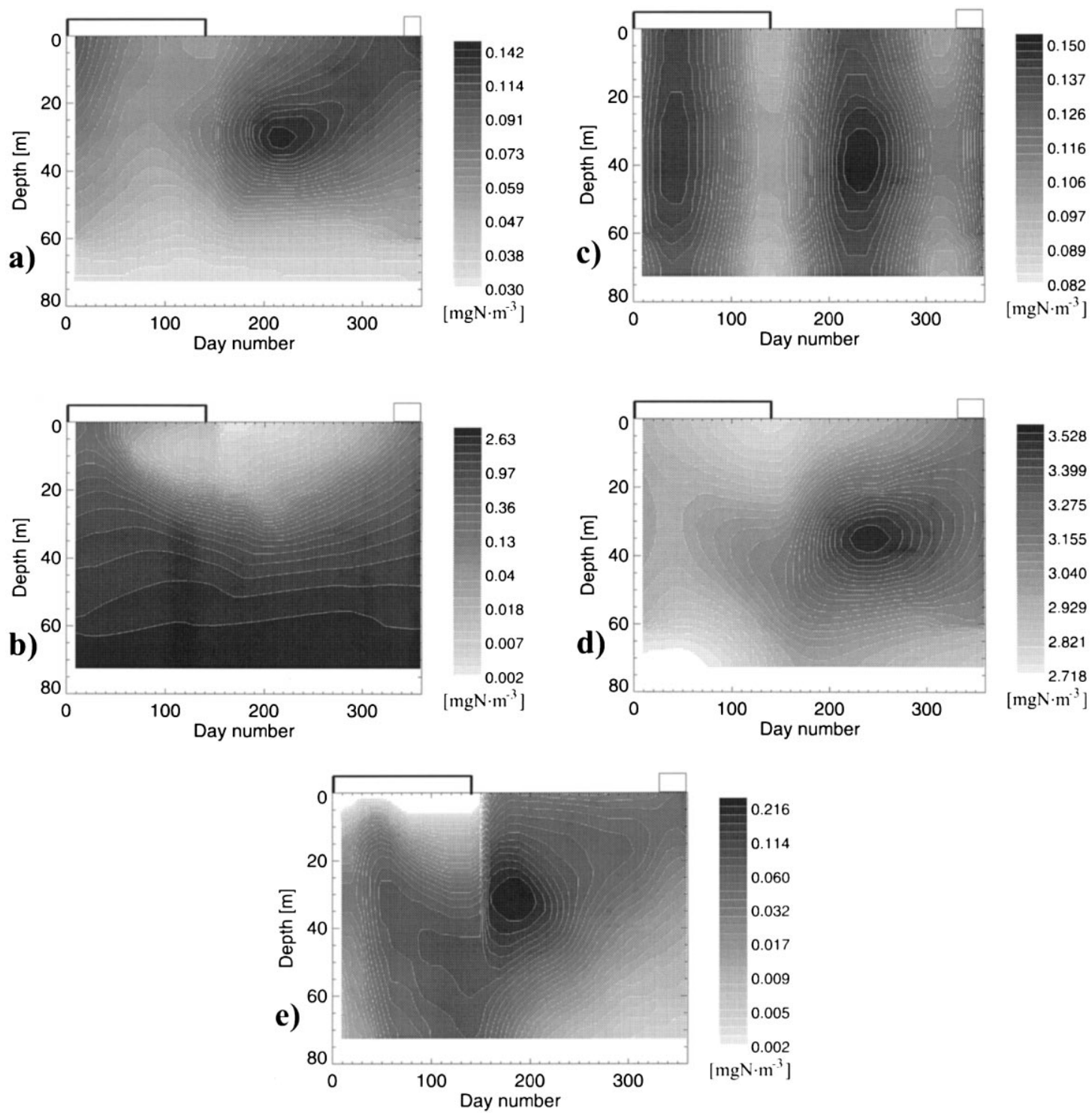

Fig. 4. Model realisation for the Lake Baikal (random snow coverage): annual cycles of (a) zooplankton; (b) nutrients; (c) bacteria; (d) autochtonic DOM; and (e) detritus (all concentrations in $\left(\mathrm{mgN} \mathrm{m}^{-3}\right)$ ).

there are no detailed data published for the vertical phytoplankton distribution and its annual change. This does not allow verification of the model.

It is widely known that phytoplankton annual cycles in Lake Baikal feature significant interannual variability. Possibly this may due to differences in ice conditions in winter, which intern changes in underwater light field.
Fig. 4 displays annual cycling of the other model state variables assuming clean ice conditions. The trends found are sufficiently similar to experimental data (Votincev et al., 1975; Izmest'eva, private communication).

The simulated under assumption of clean ice underwater spectral attenuation fields (Fig. 5a, b) in general features follow the patterns experimentally obtained by P.P. Sherstyankin (Fig. 5c, d). 

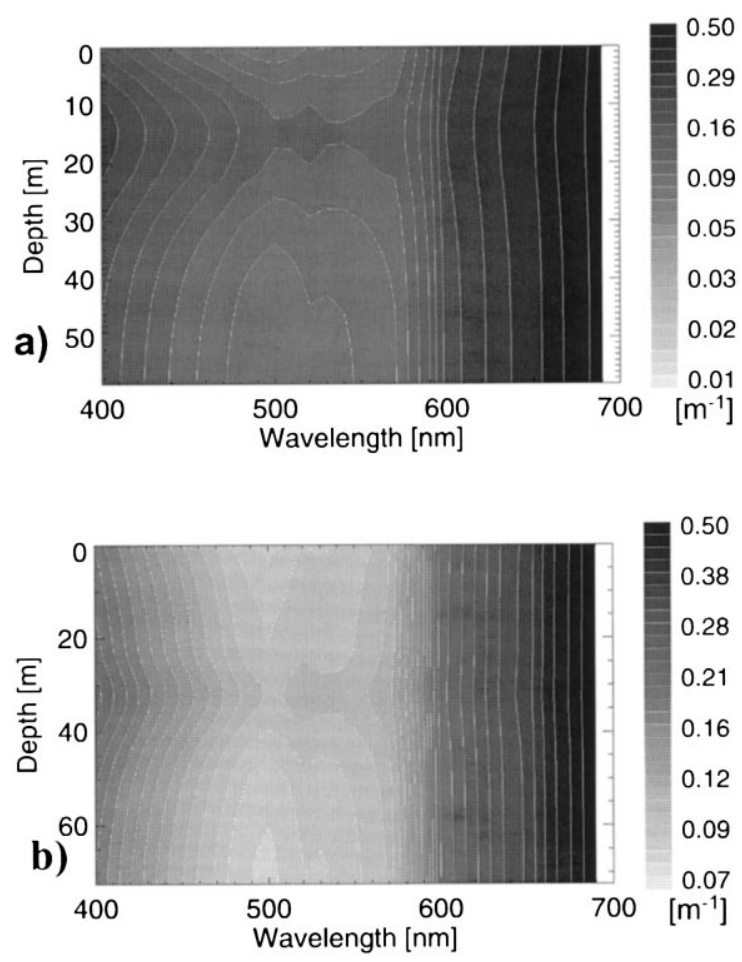
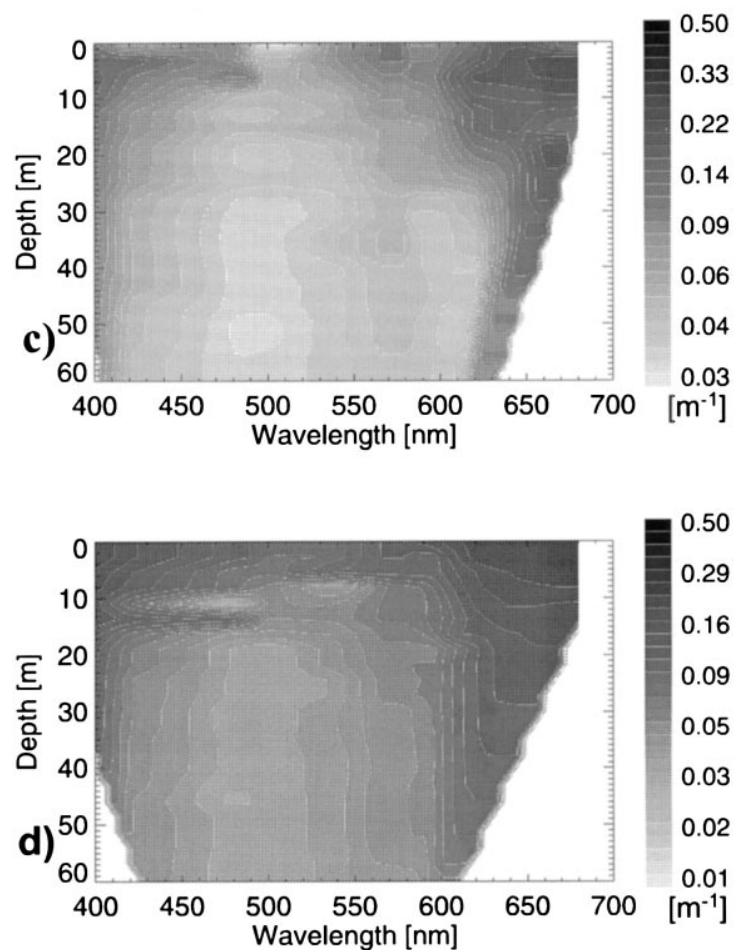

Fig. 5. Spectral diffusive attenuation coefficient $K_{\mathrm{d}}\left(\mathrm{m}^{-1}\right)$ vertical structure for the Baikal Lake. Model with clean ice: (a) April 15; (b) June 15. Observations in the Southern Baikal; (c) 23 March 1967; and (d) 17 June 1967.

The data was obtained with submersible spectrophotometer design in Limnological Institute SB RAS (Sherstyankin, 1975). The apparatus had ten interference filters for the following wavelengths: $380,420,480,500,540,586,580,620,640$ and $680 \mathrm{~nm}$. Unfortunately, the resolving power of observations is not sufficient to reveal the detailed picture. However, there is a qualitative agreement between the data and simulation.

\section{Conclusion}

Water ecosystem modeling currently addresses both multispecies and simple conceptual cases by developing more and more detailed simulations. However, there is insufficient amount of models describing accurately the dependence of primary production on specific optical conditions.

Here we presented attempt aiming specifically at the coastal and lake peculiar ecosystems. Using simple equations previously developed for the open ocean ecosystems one may obtain aberrant simulations dramatically differing from reality. Accurate estimation of numerous specific water parameters is required to obtain an adequate description of underwater optical field for the case 2 waters (see Kaczmarek and Wozniak, 1995).

Here we propose an alternative approach based upon simulation of the important ecosystem constituents, which are determine dynamics of components directly influencing underwater optical field. Although the simulations presented here represent the first attempt to apply ecodynamical modeling to underwater light field, the results obtained reasonably closely correspond to experimental data. Therefore, they might be useful for description of the dynamics of main optic factors.

On the other hand the model presented may be threaded as further development of the wellknown static models of underwater optical field (Kopelevich and Burenkov, 1977; Prieur and 
Sathyendranath, 1981; Wozniak et al., 1992, 1995, see also references in the last article). The main optical scheme upon which the model is based, in fact is the simple generalization of Prieur and Sathyendranath multicomponent model. It is important to note that the dynamic aspect added in this study enhances the predictive power of simulation. The equations of the model allow one to take into account the impact of numerous factors affecting underwater bio-optical processes. This opens the possibility of the direct coupling of remotely obtain physical data and prediction of ecologically important developments of ecosystem. Further development of the approach presented here may enable the prediction of major event such as for example, algal bloom, basing exclusively on the data from remote monitoring with subsequent numerical processing.

\section{Acknowledgements}

Author would like to appreciate the help of Professor Vadim N. Pelevin and Professor Bogdan Wozniak who introduce him to bio-optical problems. The discussions of Professor P.P. Sherstyankin and Professor M.N. Shimaraev were crucial for the deeper understanding on the Baikal mixing processes. Dr L.R. Izmest'eva provided valuable information on the variability of Baikal phytoplankton and zooplankton. Dr Dmitry Sherbakov helped in the manuscript preparation. Observational data on Baltic and Baikal spectral underwater optical fields were kindly provided by Dr Ryszard Hapter and Professor P.P. Sherstyankin. Part of the study was realized when author was with Institute of Oceanology, Polish Academy of Sciences, Sopot. Work was partially supported by Russian Foundation of Basic Research grants N 97-05-96480 and N 97-05-96521.

\section{References}

Baretta-Bekker, J.G., Baretta, J.W., Koch-Rasmussen, E., 1995. The microbial food web in the European regional seas ecosystem model. Neth. J. Sea Res. 33, 363-379.

Billen, G., 1990. Delayed development of bacterioplankton with respect to phytoplankton: A clue for understanding their trophic relationships. Ergeb. Limnol. 34, 94-98.

Carder, K.L., Steward, R.G., Harvey, G.R., Ortner, P.B., 1989. Marine humic and fulvic acids. Their effect on remote sensing of ocean chlorophyll. Limnol. Oceanogr. 34, 68-81.

Coble, P.G., Brophy, M.M., 1994. Investigation of the geochemistry of dissolved organic matter in coastal waters using optical properties. SPIE Proc. 'Ocean Optics XII' 2258, 377-389.

Dera, J., Gohs, L., Wozniak, B., 1978. Experimental study of the composite parts of the ligh-beam attenuation process in the waters of the Gulf of Gdansk. Oceanologia 10, 5-26 (in Polish).

Dobrynin, V.I., Mirgazov, R.R., Pochejkin, K.A., Tarashchanskij, B.A., 1997. Spectral light attenuation by deep Baikal waters. Opt. Atmos. Ocean 10, 234-244 (in Russian).

Gregg, W.W., Walsh, J.J., 1992. Simulation of the 1979 spring bloom in the mid-Atlantic bight: a coupled physical/biological/optical model. J. Geophys. Res. 97, 5723-5743.

Jumars, P.A., Penry, D.L., Baross, J.A., Perry, M.J., Frost, B.W., 1989. Closing the microbial loop: dissolved carbon pathway to heterotrophic bacteria from incomplete ingestion, digestion and absorption in animals. Deep-Sea Res. $36,483-496$.

Kaczmarek, S., Wozniak, B., 1995. The application of the optical classification of waters in the Baltic Sea (case 2 waters). Oceanologia 37, 285-298.

Karabashev, G.S., Kuleshov, A.F., Sherstyankin, P.P., 1989. Spectral transparency of the Baikal waters in ultraviolet and visual spectral bands. Dokl. Akad. Nauk SSSR 306, 1091-1094 (in Russian).

Kopelevich, O.V., Burenkov, V.I., 1977. On the relation between spectral properties of marine water, phytoplankton pigments and 'yellow substance'. Okeanologia 17, 427-443 (in Russian).

Korotenko, K.A., Sukhov, A.L., 1991. Experimental investigation of processes of turbulent diffusion of matter in the South and Central Basins (of Lake Baikal). In: Hydrophysics and Hydrology of Water Objects, Nauka, Novosibirsk, pp. 30-36, (in Russian).

Kowalczuk, P., Kaczmarek, S., 1996. Analysis of temporal and spatial variability of 'yellow substance' absorption in the southern Baltic. Oceanologia 38, 3-32.

Kozhov, M., 1963. Lake Baikal and its life, The Hague, Dr W. Junk 344 p.

Kozhova, O.M., Pautova, V.N., Izmest'eva, L.R., Davydova, I.K., 1985. Chlorophyll a of Lake Baikal. Hydrobiol. J. 21, 12-19 (in Russian).

Lancelot, C., Billen, G., 1990. Joint EEC Research Project on the dynamics of Phaecystis blooms in nutrient enriched coastal zones (contract EV4V-0102-B(GDF)). 2nd annual progress report.

Lignell, R., 1990. Excretion of organic carbon by phytoplankton: its relation to algae biomass primary productivity and bacterial secondary productivity in the Baltic Sea. Mar. Ecol. Prog. Ser. 68, 85-99. 
Pempkowiak, J., 1988, Distribution, sources and properties of the humic acids in the Baltic Sea, Dissertation thesis. Institute of Oceanology, Polish Academy of Sciences, Ossolineum, Wroclaw, 146 p. (in Polish).

Prieur, L., Sathyendranath, S., 1981. An optical classification of coastal and oceanic waters based on the specific spectral absorption curves of phytoplankton pigments, dissolved organic matter and other particulate material. Limnol. Oceanogr. 26, 671-689.

Samula-Koszalska, T., Wozniak, B., 1979. The share of particular sea water components in the light attenuation and analysis of the absorption spectra of yellow substances taking Gdansk Bay as an example. Stud. Mater. Oceanol. 26, 203-216.

Semovski, S.V., Wozniak, B., 1994. Model of annual phytoplankton cycle in marine ecosystem-assimilation of monthly satellite chlorophyll data for North Atlantic and Baltic. Oceanologia 37, 3-31.

Semovski, S.V., Hapter, R., Beszczynska-Moller, A., Walczowski, W., Darecki, M., Szczucka, J., Dowell, M., Staskiewicz, A., 1995. Remote sensing of mesoscale features in the Baltic coastal phytoplankton field: contact observations and models incorporating In: Proceedings of the third Thematic Conference on Remote Sensing for Marine and Coastal Environments, Seattle, WA, 18-20 September, 1995, 1, 230-242.

Semovski, S.V., Wozniak, B., Hapter, R., Staskiewicz, A., 1996. Gulf of Gdansk spring bloom physical, bio-optical and biological modeling. J. Mar. Syst. 7, 145-159.

Semovski, S.V., Sherstyankin, P.P., 1997. Bio-optical ecodynamic model for the Lake Baikal phytoplankton annual variability, Seventh International Conference on Lakes Conservation and Management, LACAR97, Sao Martin de los Andes Argentina 2, 47-50.
Sherstyankin, P.P., 1975, Experimental investigations of the lake Baikal under-ice light field. Nauka, Moscow, 92 p. (in Russian).

Shimaraev, M.N., Verbolov, V.I., Granin, N.G., Sherstyankin, P.P., 1994. Physical limnology of Lake Baikal: a review, Baikal International Center for Ecological Research, preprint No. 2, Irkutsk-Okayama, $80 \mathrm{p}$.

Siegel H., Herth, M., Beckert, M., 1994. The variation of optical properties in the Baltic Sea and algorithms for the application of remote sensing, SPIE Proc., Ocean Optics XII, 2258, 894-905.

Silow, E.A., Gurman, V.J., Stom, D.J., Rosenraukh, D.M., Baturin, V.I., 1995. Mathematical models of Lake Baikal ecosystem. Ecol. Model. 82, 27-39.

Sundermann, J., 1993. Suspended matter in the North Sea: Field observations and model simulations. Phil. Trans. R. Soc. London A 343, 423-430.

Votincev, K.K., Meshchryakova, A.I., Popovskaya, 1975, Organic matter turnover in the Lake Baikal. Nauka, Novosibirsk, 188 p. (in Russian).

Witek, Z., 1995, Biological production and its utilisation within a marine ecosystem in the Western Gdansk basin, Sea Fisheries Institute, Gdynia, 146 p. (in Polish).

Wozniak, B., Montwill, K., 1973. The methods and techniques of the optical measurements in the sea. Stud. Mater. Oceanol. 7, 73-108.

Wozniak, B., Dera, J., Koblenz-Mishke, O.J., 1991. Modelling the relationship between primary production, optical properties, and nutrients in the sea, Proc., SPIE Ocean Optics XI, 1750, 246-275.

Wozniak, B., Dera, J., Semovski, S.V., Ostrowska, M., Kaczmarek, S., 1995. Modeling of Baltic primary production, Stud. Mater. Oceanol. 68; Mar. Phys. 8, 91-123. 